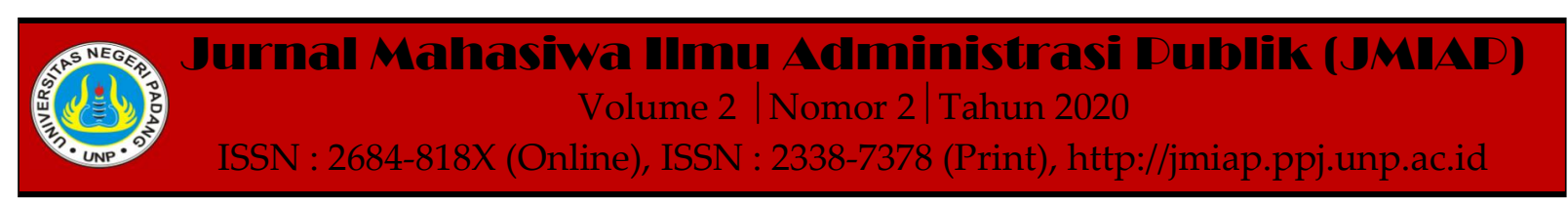

\title{
EFEKTIVITAS BADAN USAHA MILIK NAGARI DALAM MENINGKATKAN PENDAPATAN ASLI NAGARI DI NAGARI KATAPING KABUPATEN PADANG PARIAMAN
}

\author{
Anisa Safitri ${ }^{1(a)}$, Jumiati $^{2(b)}$ \\ ${ }^{1}$ Jurusan Ilmu Administrasi Negara, Universitas Negeri Padang \\ ${ }^{2}$ Jurusan Ilmu Administrasi Negara, Universitas Negeri Padang \\ a)anisasafitri666@gmail.com, ${ }^{b)}$ jumiati@fis.unp.ac.id
}

\begin{abstract}
The purpose of this research is to describe and understand first, how the effectiveness of Nagari Owned Enterprises in increasing Nagari Original Income in Nagari Kataping second, what are the obstacles encountered in making Nagari Owned Enterprises effective in increasing Nagari Original Income in Nagari Kataping third, what efforts are being made to make Nagari-Owned Enterprises effective in increasing Asli Nagari's income in Nagari Kataping. This research uses qualitative methods and descriptive approaches. The research was conducted at Nagari Kataping location, Batang Anai District, Padang Pariaman Regency. Research informants are determined by technique purposive sampling. The data used in this research are secondary data and primary data. Data collection was carried out by means of observation, interviews, and documentation. So that the data obtained can be concluded from the data obtained in the field. The conclusion of this study is the effectiveness of Nagari-owned enterprises (BUMNag) in increasing Nagari Original Income in Nagari Kataping can not be effective. This is because in the management of the Nagari-Owned Enterprises (BUMNag) business unit that is less competent, the results of the business being managed have no development and are estimated to be losing money.
\end{abstract}

Keywords : Effectiveness, Village Owned Busniness Entity, Original Villege Income

Corresponding author. Email.anisasafitri666@gmail.com,jumiati@fis.unp.ac.id

How to cite this article. Safitri, A \& Jumiati. (2020). Efektivitas Badan Usaha Milik Nagari dalam Meningkatkan Pendapatan Asli Nagari di Nagari Kataping Kabupaten Padang Pariaman. Jurnal Mahasiwa Ilmu Administrasi Publik (JMIAP) Jurusan Ilmu Administrasi Negara Fakultas Ilmu Sosial Universitas Negeri Padang, Volume 2 (2), Hal. 90-97.

http://jmiap.ppj.unp.ac.id

ISSN : 2684-818X (Online), ISSN : 2338-7378 (Print)

Copyright $(2020$. Published by Pusat Kajian-Pemberdayaan dan Pelayanan Masyarakat (PK-P2M) FIS UNP Padang 


\section{PENDAHULUAN}

Satu kesatuan masyarakat hukum yang memiliki batas wilayah, yang berwenang untuk mengatur dan mengurus urusan pemerintahan, kepentingan masyarakat setempat berdasarkan prakarsa masyarakat, hak asal usul, dan/atau hak tradisional yang diakui dan dihormati dalam sistem pemerintahan Negara Kesatuan Republik Indonesia (NKRI) disebut dengan Desa yang tercantum dalam UU Nomor 6 Tahun 2014 tentang Desa. Desa sebagai wakil negara dibagian sistem pemerintahan di bawah, Desa perlu melakukan pembangunan yang di awali pada perbaikan terhadap pengembangan kualitas SDM maupun pembangunan secara fisik, sebagai upaya untuk meningkatkan prekonomian masyarakat Desa.

Dalam rangka peningkatan pertumbuhan ekonomi masyarakat serta meningkatkan Pendapatan Asli Desa, Menteri Desa memberikan dana kepada Desa guna merangsang masyarakat ikut serta aktif dalam melaksanakan pembangunan. Desa di tempatkan sebagai "kekuatan besar" untuk mencapai kemajuanprekonomian indonesia. oleh sebab itu, Undang-Undang No.6 Th 2014 tentang Desa pada masa pemerintahan Presiden Jokowi-JK menjadi desa prioritas penting sebagai tonggak pembangunan Indonesia.

Dengan lahirnya Undang-Undang tentang Desatersebut merubah sudut pandang tentang desa dari sebagai objek menjadi salah satu subjek yang berpengaruh dalam pembangunan yang termasuk dalam NKRI. Desa ialah suatu sub sistem dari pemerintahan yang terendah atau terkecil, yang dekat langsung menyentuh kehidupan dan kebutuhan masyarakat dalam rangka mencapai kesejahteraan maka perlunya desa untuk dapat mengurus kepentingan masyarakat. maka dibentuklah suatu kelembangan yang mana kelembagaan tersebut bernama Badan Usaha Milik Desa (BUMDes).

Lahirnya BUMDes merupakan sebagai suatu ancangan untuk peningkatan pendapatan bagi perekonomian di perdesaan dengan memberdayakan dan mengelola segala sumber daya yang dimiliki secara optimal. Untuk pengelolaan BUMDes dilaksanakan dan dikelola langsung oleh masyarakat Desa. Tugas BUMDes yaitu menampung usaha-usaha masyarakat atau hasil kebun dari masyarakat ataupun mengelola sumber daya miliki desa yang dikelola secara profesional. maka, Untuk dapat menjadikan usaha agar produktif dan efektif maka perlu dikelola dengan baik, agar dapat memberikan peningkatkan pendapatan asli desa.

Dengan adanya BUMDes diharapkan dapat memberikan hasil positif untuk kehidupan ekonomi di perdesaan. Pemberlakuan Undang-Undang Desa membuat pemerintah menerapkan kebijakan untuk mendirikan Badan Usaha Milik Desa di tiap-tiap perdesaan di seluruh Indonesia. Adapun BUMDes ini memiliki nama lain seperti di Sumatera Barat disebut sebagai Badan Usaha Milik Nagari. Dengan demikian berdirinya BUMNag/BUMdes segala potensi yang dimiliki diharapkan dapat diberdayakan untuk peningkatkan kesejahteraan masyarakat dan pendapatan asli nagari. Oleh karena itu, nagari sebagai perwakilan negara pada pemerintahan dibawah mengharuskan untuk melaksanakan pembangunan yang dilakukan secara fisik atau perbaikan pada SDM, suatu bentuk upaya dari peningkatan kesejahteraan dan bentuk perbaikan kualitas hidup.

Dalam Permendes PDTT No. 4 Tahun 2015, disebutkan pada pasal 1 (2) BUMDes merupakan badan usaha yang seluruh atau sebagian besar modalnya dimiliki oleh Desa melalui penyertaan secara langsung yang berasal dari kekayaan Desa yang dipisahkan guna mengelola aset, jasa pelayanan dan usaha lainnya untuk sebesar-besarnya kesejahteraan masyarakat..Desa.

Badan Usaha Milik Nagari (BUMNag) lahir sebagai suatu ancangan untuk meningkatan ekonomi nagari berdasarkan kebutuhan dan pemanfaatan sumber daya yang dimiliki nagari. Pengelolaan 
BUMNag seluruhnya dilakukan oleh masyarakat nagari dan pemerintah nagari, yakni dari nagari, oleh nagari dan untuk nagari. Pendirian kelembagaan BUMNag ini sangat penting, sebab akan memberikan dampak dan manfaat kepada masyarakat nagari maupun nagari karena dapat memberikan keuntungan pada taraf perekonomian keduannya. Diharapkan Dengan lahirnya BUMNag dapat menjadi tonggak kesejahteraan bagi masyarakat, karena BUMNag didirikan berdasarkan kesepakatan bersama masyarakat Desa, yaitu suatu kelompok masyarakat yang saling bekerja sama, bergotong royong untuk dapat meningkatkan perekonomiannya.

Sumatera Barat tersebar ke dalam 803 Nagari dan 126 Desa (sumber: Langgam.id, 18 Januari 2020). Indeks Pembangunan Desa (IPD) 2018 untuk semua nagari ini mencapai 67,70 persen tertinggi di Pulau Sumatera. Namun pemerintah dan masyarakat masih perlu bahu-membahu membangun nagari karena hanya ada satu dari lima nagari yang sudah mandiri. Selain itu, masih ada sebanyak 31 nagari tertinggal di Sumatera Barat, termasuk di daerah Kabupaten Padang Pariaman (sumber: Kompasiana.com, Oktober 2019).

Kabupaten Padang Pariaman secara geografi memiliki luas wilayah $1.328,79$ $\mathrm{km} 2$ dengan panjang garis pantai $42,1 \mathrm{Km}$. Dengan wilayah yang sangat luas Kabupaten Padang Pariaman mempunyai lahan pertanian dan perkebunan (sumber: padangpariamankab.go.id). Nagari Kataping salah satu nagari yang berada di Kabupaten Padang Pariaman, memiliki sejumlah potensi yang mendukung diberdayakan untuk meningkatkan taraf perekonomian. Kabupaten Padang Pariaman telah berdiri 56 BUMNag di setiap Nagari, dimulai sejak Tahun 2016 serta dibentuk struktur organisasi kepengurusan dan usaha yang dikelola melalui musyawarah yang menghadirkan seluruh perangkat kenagarian dan sebagaian masyarakat.
Sebanyak 56 BUMNag yang berdiri di Kabupaten Padang Pariaman tidak seluruhnya dalam pengoperasian BUMNag berjalan dengan baik di setiap Nagari. salah satunya adalah Nagari Kataping, Penulis mendapati kendala pada BUMNag "Kataping Jaya Sejahtera". Kendala tersebut yaitu ada pada pengelola operasional, dimana sumber daya manusia dalam hal pengelolaan usaha masih kurang mumpuni. Dengan rendahnya kualitas dan pengetahuan sumber daya manusia akan berpengaruh pada usaha yang dikelola sehingga usaha tersebut tidak memiliki perkembangan. Kendala selanjutnya, kurangnya partisipasi masyarakat Nagari terhadap BUMNag. Hal ini dikarenakan sosialisasi yang diberikan oleh Wali Nagari kepada masyarakat tidak menyeluruh, sehingga sebagian masyarakat banyak tidak mengetahui adanya BUMNag dan tidak mengetahui maksud dan tujuan didirikannya BUMNag di Nagari Kataping. Padahal jika dilhat dari kondisi geografis Nagari Kataping cukup memiliki potensi yang menguntungkan jika pada pemanfaatnya dikelola dengan baik sehingga dapat memberikan masukan berupa pendapatan bagi Nagari dan peningkatan ekonomi masyarakat Nagari. Selain itu, kendala yang ditemui yaitu pada penggunaan lahan sewa yang tidak dipakai secara menyeluruh.

Berdasarkan penjelasan diatas, peneliti tertarik untukmelakukan penelitian dengan judul Efektivitas Badan Usaha Milik Nagari (BUMNag) dalam Meningkatkan Pendapatan Asli Nagari di Nagari Kataping Kecamatan Batang Anai Kabupaten Padang Paraiaman. Rumusan masalah pada penelitian adalah sebagai berikut:

1) Bagaimana Efektifitas Badan Usaha Milik Nagari (BUMNag) dalam meningkatkan pendapatan nagari di Nagari Kataping?

2) Apa kendala yang ditemui dalam mengefektifkan Badan Usaha Milik Nagari (BUMNag) serta apa upaya yang dilakukan untuk mengefektifkan? 


\section{TINJAUAN PUSTAKA}

\section{Efektivitas}

Efektivitas merupakan kemampuan organisasi dalam melakukan pencapaian tujuan ataupun sasaran melalui program ataupun kegiatan organisasi dapat dikatakan efektif apablia sudah tercapainya sasaran dan tujuan dalam organisasi tersebut (Hanny, 2016).

Efektivitas sebagai pengukur alternatif untuk dapat mencapai hasil yang diharapkan berdasarkan pada hasil tindakan yang diadakan oleh organisasi Dunn (2003:429). Dalam hal ini menunjukkan bahwa indikator efektivitas sebagai sub sistem untuk mencapai sasaran ataupun tujuan yang telah ditentukan. maka indikator digunakan sebagai pengukur, dimana target yang telah ditetapkan dapat tercapai. Untuk mengukur efektivitas Badan Usaha Milik Nagari (BUMNag) dalam meningkatkan Pendapatan Asli Nagari digunakan standar pengukuran yang dipaparkan oleh P.Siagian (1983:35) yaitu sebagai berikut :

a) Kejelasan Tujuan yang Hendak Dicapai.

b) Kejelasan Strategi Pencapaian Tujuan.

c) Proses Analisa Perumusan dan Kebijakan yang Mantap.

d) Perencanaan Yang Matang.

e) Penyusunan Program Yang Tepat.

f) Tersedianya Sarana dan Prasaranakerja.

g) Pelaksanaan Tugas Yang Efektif Dan Efisien.

h) Sistem Pengawasan dan Pengendalian Yang Bersifat Mendidik.

\section{Badan Usaha Milik Nagari}

Badan Usaha Milik Desa (BUMDes) didefinisikan sebagai kelembagaan bisnis yang dibentuk dalam upaya menguatkan ekonomi desa, serta pendiriannya didasarkan pada kebutuhan masyarakat desa dan pemanfaat sumber daya yang dimiliki Desa. selanjutnya, BUMDes ialah suatu badan usaha milik desa yang didirikan untuk dapat memenuhi kebutuhan masyarakat serta mengelola sumber daya Desa sebagai bentuk peningkatan pendapatan dan kesejateraan pada kehidupan masyarakat buku panduan BUMDes Departemen Pendidikan Nasional (2007:4). Sedangkan Menurut Anom Surya Putra (2015: 9) mengatakan bahwa BUMDes merupakan strategi kebijakan pemerintah untuk menghadirkan kelembagaan negara dalam kehidupan masyarakat di Desa.

BUMNag suatu badan perekonomian berbadan hukum, serta kepemilikannya dimiliki Pemerintahan Nagari, dikelola dengan profesional, ekonomis, kemudian pada permodalan BUMNag seluruhnya atau sebagian besar berasal dari kekayaan nagari yang dipisahkan. BUMNag didirikan untuk dapat memperoleh keuntungan, memberikan kontribusi pada peningkatan perekonomian masyarakat, perekonomian nagari, dan peningkatan asli Nagari (PANag).

Berdasarkan penjelasan diatas BUMDesa/BUMNag yaitu lembaga ekonomi yang berfungsi sebagai roda penggerak perekonomian masyarakat dan Nagari dengan melakukan pemanfaatan sumber potensi yang dikelola oleh BUMNag.

Pendirian BUMDes memiliki empat tujuan utama sebagai lembaga ekonomi berbasis kerakyatan, yaitu : pertama, memperbaiki ekonomi desa. kedua, memperbaiki Pendapatan Asli Desa. ketiga, memanfaatkan sumber daya dimiliki desa sesuai dengan kebutuhan masyarakat, dan keempat, sebagai tulang punggung yang menjadi pertumbuhan dan pemerataan ekonomi Desa. Agar tercapainya sasaran dari pendirian BUMNag, peran serta tugas pemerintah nagari sangat diperlukan dengan mensosialisasikan dan memberikan pengetahuan kepada masyarakat arti penting dari pendirian BUMNag dengan tujuan utama meningkatkan perekonomian. Melalui pemerintahan nagari masyarakat disadarkan, dimotivasi, dan dipersiapkan untuk memenuhi kebutuhannya sendiri. Sedangkan pemerintah pusatbertugas untuk memfasilitasi dengan memberikan pendidikan, pelatihan dan lainnya. 


\section{Meningkatkan Pendapatan Asli Nagari}

Dalam KBBI mendefinisikan

pendapatan merupakan hasil usaha atau upah dan sebagainya. Definisi pendapatan menurut Kamus Besar Bahasa Indonesia adalah pengertian pendapatan secara umum. Sedangkan Pendapatan asli nagari ialah pendapatan yang didapatkan dari hasil usaha yang dimiliki oleh pemerintah nagari serta dari pengelolaan aset nagari. kemudian, dijelaskan juga dalam Undangundang Desa No 6 tahun 2014 bahwa Pendapatan asli desa ialah berupa hasil dari usaha, hasil dari pengelolaan aset, swdaya, partisipasi,gotong royong dan lain-lainnya.

Pendapatan memiliki pengaruh yang besar, sebab pendapatan menjadi roda berjalannya pemerintahan dan pembangunan agar dapat berjalan dengan lancar. Pendapatan juga dijelaskan didalam Peraturan Menteri Dalam Negeri (permendagri) No 20 Tahun 2018 tentang Pengelolaan Keuangan Desa, bahwa Pendapatan yaitu semua yang diterima oleh desa terhitung dalam 1 tahun anggaran, menjadi hak desa dan tidak perlu dikembalikan oleh desa.

\section{METODE PENELITIAN}

Penelitian ini peneliti menggunakan metode kualitatif dengan pendekatan deskriptif. Penelitian dilakukan di Nagari Kataping Kecamatan Batang Anai Kabupaten Padang Pariaman. Pemilihan informan menggunakan teknik purposive sampling. Selanjutnya, data dikumpulkan dengan melakuan observasi atau pengmatan, interview dan melakukan dokumentasi. Untuk menguji keabsahan data pada penelitian ini yaitu dengan teknik metode dan triangulasi sumber. Sehingga data yang didapatkan dilapangan dapat ditarik kesimpulan.

\section{HASIL DAN PEMBAHASAN}

BUMNag adalah lembaga yang didirikan sebagai penguatan perekonomian Nagari yang dikelola secara bersama. Dalam Undang-Undang No. 32 Tahun 2004 tentang Pemerintahan Daerah,
BUMNag/BUMDes pendiriannya untuk dapat meningkatkan Pendapatan Asli Desa (PADes) dan untuk kesejahteraan masyarakat. Jika pendapatan asli nagari didapatkan dari BUMNag besar, maka hal tersebut akan membuat masyarakat memberikan perhatian lebih dalam merespon pedirian BUMNag.

Berkaitan dengan efektivitas Badan Usaha Milik Nagari (BUMNag) dalam meningkatkan pendapatan asli nagari di Nagari Kataping dilihat dari delapan indikator sebagai tolak ukur efektivitas yang dikemukakan oleh Sondang P. Siagan (1983: 32-35) yaitu sebagai berikut:

\section{Kejelasan Tujuan yang Hendak Dicapai}

Efektivitas merupakan keberhasilan organisasi yang berfungsi secara efektif dalam pencapaian tujuannya Sondang P.Siagian (1983:32). Berdasarkan penelitian yang telah dilakukan di BUM Nagari Kataping Jaya Sejahtera, pada kejelasan tujuan yang hendak dicapai oleh Badan Usaha Milik Nagari Kataping Jaya Sejahtera sudah jelas tujuannya. Hal ini dibuktikan dari usaha yang dikelola salah satunya unit usaha jasa pelayanan online, yang telah membantu memenuhi masyarakat dalam hal pembayaran listrik dan PDAM.

Untuk mencapai tujuan BUMDes langkah awal yaitu dengan menyediakan pelayanan barang dan jasa yang menjadi kebutuhan masyarakat dalam Buku Panduan BUMDes (2007:5-6). Dari penjelasan tersebut dapat dilihat, untuk tercapainya tujuan adalah dengan memenuhi kebutuhan masyarakat baik dari aspek kehidupan maupun melalui pelayanan barang dan jasa.

\section{Kejelasan Strategi Pencapaian Tujuan}

Menurut Sondang P. Siagian (1983: 35) Kejelasan Strategi sebagai langkah dalam pelaksanaan tugas untuk mencapai sasaran atau tujuan yang ditentukan. Maka, kejelasan strategi sangat penting karena strategi tepat merupakan cara untuk mencapai target atau sasaran yang menjadi 
tujuan organisasi. Dalam hal ini strategi pencapaian tujuan BUMNag yaitu kerja sama antara wali korong dan petugas BUMNag untuk mensosialisasikan usaha BUMNag kepada masyarakat, kemudian petugas BUMNag melakukan pengenalan usaha melalui akun media sosial seperti Facebook dan Whatapp.

\section{Proses Analisa dan Perumusan Kebijakan yang Mantap}

Menurut Yasmine,dkk (2016 Vol.1 No.1) mengatakan bahwa perumusan kebijakan merupakan suatu proses yang dilakukan dengan mengidentifikasi dan menganalisis untuk memecahkan permasalahan dengan melibatkan para aktor yang terlibat untuk menghasilkan tindakan didalamnya.

Dari pendapat Yasmine dapat dijelaskan bahwa pada proses perumusan kebijakan yang dilaksanakan Wali Nagari Kataping dalam pendirian Badan Usaha Milik Nagari (BUMNag) dihadiri oleh perangkat nagari, Bamus, Wali Korong, petugas BUMNag, pendamping Desa dan Masyarakat Nagari. Proses dan perumusan kebijakan yang dibuat telah menyesuaikan peraturan berdasarkan Undang-Undang, Peraturan Menteri Desa dan Perda Kabupaten Padang Pariaman yang berlaku tentang pendirian Badan Usaha Milik Nagari. Dapat disimpulkan bahwa perumusan kebijakan terlaksana dengan baik mengikuti peraturan yang berlaku.

\section{Perencanaan yang Matang}

Menurut Sondang P. Siagian (1983:35) bahwa keahlian dalam menghasilkan merumuskan perencanaan dengan matang dapat dilihat ketika suatu organisasi mampu mengambil keputusan yang tepat dengan mempertimbangkan segala resiko dan memprediksi situasi yang akan dihadapi di masa depan. Dalam hal ini kemampuan merumuskan perencanaan yang matang dalam usaha yang dikelola lembaga Badan Usaha Milik Nagari (BUMNag) Kataping Jaya Sejahtera belum semuanya terealisasikan dengan baik. Dapat dilihat dari usaha yang dikelola tidak berjalan dengan yang diharapkan, seperti usaha pertanian penanaman bibit jagung yang mengalami kerugian dan kegagalan akibat kurangnya pemahaman dan pengelolaan budidaya pada tanaman jagung serta pemanfaatan lahan sewa yang kurang optimal.

\section{Penyusunan Program yang Tepat}

Menurut Sondang P. Siagian (1983: 34) yaitu suatu rencana dapat dikatakan baik, jika dijabarkan kedalam program-program kegiatan pelaksanaan agar berjalan dengan tepat. Sedangkan menurut Yosifa (2016 Vol.3 No.2) mengatakan bahwa penyusunan program yang tepat ialah sutau rencana yang disusun menggambarkan secara konkret pelaksanaan kegiatan dalam suatu program.

Dari pendapat Sondang dan Yosifa dapat dijelaskan bahwa apabila tidak dijabarkan dalam program-program kerja, maka pelaksana tidak akan tahu atau kurang memiliki petunjuk untuk melaksanakan tugas. Berdasarkan penelitian yang didapat di lapangan, ditemui bahwa penyusunan pelaksanaan kerja dapat dikatakan baik, dapat dilihat dari pembagian tugas yang jelas oleh masing-masing bidang kepala unit usaha. Akan tetapi, hasil kerja melalui penyusunan program kerja belum optimal dalam mencapai tujuan mengefektifkan badan usaha untuk meningkatkan pendapatan nagari.

\section{Tersedianya Sarana dan Prasarana Kerja}

Menurut Sondang P. Siagian (1983:35) ketersediaan sarana dan prasarana merupakan bagian penting guna untuk menunjang kinerja didalam suatu organisasi agar dapat bekerja secara produktif. Sedangkan menurut Yosifa (2016 Vol.3 No.2) mengatakan bahwa sarana dan prasarana adalah faktor utama yang memiliki peran masing-masing berguna dalam menunjang proses kegiatan organisasi. Sesuai apa yang telah dijelaskan diatas bahwa untuk mencapai keberhasilan 
diperlukannya sarana dan prasarana yang mendukung kinerja petugas pengelola agar tujuan dapat tercapai. Oleh karena itu, fasilitas penunjang kinerja sangat diperlukan agar petugas pengelola dapat bekerja secara produktif agar dapat mencapai tujuan. Berdasarkan penelitian dilapangan ketersediaan sarana dan prasarana yang menunjang usaha di Kantor BUMNag masih terbatas. Contohnya gudang sebagai fasilitas untuk penyimpan barang dari usaha jual beli pinang belum ada. Jadi, untuk ketersediaan sarana dan prasarana yang dibutuhkan pada fasilitas usaha belum terpenuhi.

\section{Pelaksanaan Tugas yang Efektif dan Efisien}

Dalam mencapai tujuan diperlukan melaksanaan tugas dengan efektif dan efisien. Untuk dapat terlaksana secara efektif dan efisien maka diperlukannya penyusunan program dengan jelasnya tujuan, tepatnya strategi yang digunakan, proses yang tidak berbelit-belit, rencana yang matang, tepatnya penguraian rencana pada kegiatan yang sudah terprogram dan kemampuan memanfaatkan sarana dan prasarana yang terbatas perlu dilakukan agar tercapai kegiatan operasional yang efektif dan efisien. Maka dari hasil penelitian yang dilakukan, ditemukan bahwa pelaksanaan tugas dalam mengelola badan ausaha dapat dikatakan belum efektif, dilihat dari penyusunan pelaporan pembukuan selama kegiatan operasional BUMNag berjalan belum terselesaikan, pelaporan tersebut sebagai laporan akhir tahun yang diserahkan kepada Wali Nagari untuk menghitung laba bersih dan pengeluaran yang dikelola BUMNag. Hal ini menandakan bahwa pelaksanaan tugas pada pengelola BUMNag dapat dikatakan tidak efektif.

\section{Sistem Pegawasan dan Pengendalian Mendidik}

Menurut Sondang P.Siagian (1983: 35)

Pengawasan dan pengendalian juga diperlukan karena mengingat bmanusia memiliki segala kekurangan, maka dalam pelaksanaan pengukuran efektivitas sangat di perlukan adanya sistem pengawasan dan pengendalian. Berdasarkan yang ditemui di lapangan bahwa badan usaha milik nagari (BUMNag) memiliki badan pegawas dalam mengawasi berjalannya badan usaha agar tidak ada penyimpangan dalam pelaksanaan tugas operasional BUMNag. Selanjutnya, pengendalian yang mendidik yang didapati oleh petugas badan usaha milik nagari yaitu langkah awal membuka usaha berdasarkan kebutuhan masyarakat, penyusunan RAB, dan pelaporan pembukuan.

Berdasarkan hasil penelitian dilapangan dapat dilihat bahwa masih terdapat kendala yang ditemui pada indikator pengukur pengefektifan BUMNag.

\section{PENUTUP}

Berdasarkan hasil penelitian diatas dapat disimpulkan : (1) Pendirian kelembagaan BUMNag di Nagari Kataping Kecamatan Batang Anai Kabupaten Padang Pariaman belum berjalan efektif karena terlihat dari kualitas sumber daya manusia sebagai pengelola BUMNag yang masih terbilang rendah. (2) Badan Usaha Milik Nagari (BUMNag) Kataping Jaya Sejahtera sama sekali belum memberikan peningkatan pada pendapatan asli nagari terlihat dari laporan pembukuan hingga saat ini belum selesai, (3) Pemberian sosialisasi yang tidak menyeluruh oleh pihak Wali Nagari mengakibatkan rendahnya pasrtisipasi masyarakat terhadap pengelolaan Badan Usaha yang seharusnya dikelola secara bersama sehingga dapat mencapai keberhasilan yang berdampak pada peningkatan perekonomian masyarakat dan Nagari, dan (4) kurangnya pemanfaatan lahan sewa oleh pengelola Badan Usaha Miliki Nagari sehingga menjadi terbengkalai. (5) kemacetan pada usaha BUMNag sehingga kegiatan operasional di berhentikan hingga batas waktu yang tidak ditentukan. Kemudian untuk mengatasi permasalahan pada Badan Usaha ialah dengan melakukan penataan ulang pengelola BUMNag yaitu mengganti 
petugas pengelola dengan petugas yang memiliki kemampuan untuk mengelola BUMNag tersebut serta memilih pengurus yang memang memiliki kemampuan dan pemahaman berwirausaha agar pengelolaan BUMNag dapat memberikan hasil yang menguntungkan sesuai dengan tujuan yang tercermin di dalam Undang-Undang yaitu memberdayakan masyarakat, peningkatan pada Pendapatan Asli Nagari dan Masyarakat, dan menjadi penggerak perekonomian masyarakat.

\section{DAFTAR KEPUSTAKAAN}

Anonim. (2007). No Title. In Buku Panduan Pendirian dan Pengelolaan Badan Usaha Milik Desa (BUMDes), Departemen Pendidikan Nasional Pusat Kajian Dinamika Sistem Pembangunan (PKDSP) (p. 86). Fakultas Ekonomi Universitas Brawijaya Malang.

Pada, S., Di, B., \& Kidul, G. (2016). Kesejahteraan Masyarakat Pedesaan, 28(2), 155-167.

Peraturan Daerah Provinsi Sumatera Barat No 7 Tahun 2018 tentang Nagari.

Permendes PDTT No. 4 Tahun 2015 tentang Pendirian, Pengurusan Dan Pengelolaan, Dan Pembubaran Badan Usaha Milik Desa.

Sondang P. Siagian. (1983). Bunga Rampai Manajemen Modern (pp. 32-35). Jakarta: Gunung Agung.

Suharyanto, \& Hastowiyono. (2014). No Title. In S. E. Yunanto (Ed.), Seri Buku Pintar BUM Desa Pelembagaan BUM $\operatorname{Des} A$ (p. 78). Forum Pengembangan Pembaharuan Desa (FPPD).

Undang-Undang Nomor 6 Tahun 2014 Tentang Desa

Yasmine. (2016). No Title. Journal of Public and Management Review, 1 No 1(Analisis Aktor Pembentukan BUMDES Pagedangan Cahaya Madani Perspektif Governance), 5

Yulyana, E., Si, M., \& Ap, M. (2016). Efektivitas Pengelolaan Badan Usaha Milik Desa (BUM DESA) Berbasis Ekonomi Kerakyatan Di Desa Warungbambu Kecamatan Karawang, $1(2), 31-42$. 